The University of San Francisco

USF Scholarship: a digital repository @ Gleeson Library |

Geschke Center

Economics

College of Arts and Sciences

2014

\title{
Got Milk? The Impact of Heifer International's Livestock Donation Programs in Rwanda on Nutritional Outcomes
}

Rosemary Rawlins

Svetlana Pimkina

Christopher B. Barrett

Sarah Pedersen

Bruce Wydick

University of San Francisco, wydick@lucas.usfca.edu

Follow this and additional works at: http://repository.usfca.edu/econ

Part of the Economics Commons

\section{Recommended Citation}

Rosemary Rawlins, Svetlana Pimkina, Christopher B. Barrett, Sarah Pedersen, Bruce Wydick. Got milk? The impact of Heifer International's livestock donation programs in Rwanda on nutritional outcomes. Food Policy. Volume 44, February 2014, Pages 202-213. DOI: $10.1016 /$ j.foodpol.2013.12.003

This Article is brought to you for free and open access by the College of Arts and Sciences at USF Scholarship: a digital repository @ Gleeson Library | Geschke Center. It has been accepted for inclusion in Economics by an authorized administrator of USF Scholarship: a digital repository @ Gleeson Library| Geschke Center. For more information, please contact repository@usfca.edu. 


\title{
Got Milk? The Impact of Heifer International's Livestock Donation Programs in Rwanda on Nutritional Outcomes
}

\author{
Svetlana Pimkina ${ }^{1}$ \\ Rosemary Rawlins ${ }^{1}$ \\ Christopher B. Barrett ${ }^{2}$ \\ Sarah Pedersen ${ }^{3}$ \\ Bruce Wydick ${ }^{4}$
}

November 2013 revised version

\begin{abstract}
International animal donation programs have become an increasingly popular way for people living in developed countries to transfer resources to families living in developing countries. We evaluate the impact of Heifer International's dairy cow and meat goat donation programs in Rwanda. We find that the program substantially increases dairy and meat consumption among Rwandan households who were given a dairy cow or a meat goat, respectively. We also find marginally statistically significant reductions in weight-for-height $z$-scores and weight-for-age $z$-scores of about 0.4 standard deviations among children aged 0-5 years in households that were recipients of meat goats, and reductions in heightfor-age $z$-scores of about 0.5 standard deviations among children in households that received dairy cows. Our results suggest that increasing livestock ownership in developing countries may significantly increase consumption of nutrient dense animal-source foods and improve nutrition outcomes.
\end{abstract}

${ }^{1}$ Graduate students, Department of Economics, University of San Francisco, 2130 Fulton Street, San Francisco, CA 94117-1080, e-mails: s.pimkina@gmail.com,rjrawlins@gmail.com. 2Stephen B. \& Janice G. Ashley Professor of Applied Economics and Management, International Professor of Agriculture and Professor of Economics, $301 \mathrm{G}$ Warren Hall, Cornell University, Ithaca, NY 14853-7801, e-mail: cbb2@cornell.edu. ${ }^{3}$ Doctoral Student, International Nutrition, Cornell University, Ithaca, NY 148537801, e-mail:sp729@cornell.edu. ${ }^{4}$ Professor of Economics, Department of Economics, University of San Francisco, 2130 Fulton Street, San Francisco, CA 94117-1080, e-mail: reydick@usfca.edu. We are grateful to Rienzzie Kern and the staff at Heifer International for encouragement and logistical assistance and to Cornell University, the National Science Foundation-supported Food Systems and Poverty Reduction IGERT, and the University of San Francisco's Masters program in International and Development Economics for financial support, as well as to two anonymous reviewers for helpful comments. Any remaining errors are the authors' sole responsibility. 


\section{Got Milk? The Impact of Heifer International's Livestock Donation Programs in Rwanda on Nutritional Outcomes}

\section{Highlights}

Heifer International's livestock donation programs have a significant impact on household diets and child nutrition in Rwanda.

In households that receive a dairy cow:

- members consume an average of 1.2 more food groups in the last two days, indicating a statistically and practically significant impact on dietary diversity.

- members consume nearly three times as much dairy as otherwise identical nonrecipients. Receiving a Heifer cow one year ago is associated with a statistically significant 9.3-10.9 liter increase in monthly per-person dairy consumption compared to the control groups.

- children exhibit height-for-age z-scores that are 0.5-0.8 standard deviations higher, on average, and weight-for-age z-scores that are 0.19-0.40 standard deviations higher.

Those households that receive a meat goat:

- consume, on average, an extra 0.11-0.20 kilograms of meat per person per month, nearly doubling recipients' meat intake.

- have children whose weight-for-height z-scores are 0.47 standard deviations higher, on average, and weight-for-age $\mathrm{z}$-scores that are 0.42-0.76 standard deviations higher. 


\section{INTRODUCTION}

The Food and Agricultural Organization of the United Nations estimates that worldwide 870 million people are undernourished (FAO, 2012). One-third of the world's children are affected by delayed growth and development due to malnutrition, in addition to the 40 thousand children who die each day from malnutrition-related causes (Behrman et al., 2003). In many developing countries, decades of foreign aid appear to have had little impact on reducing poverty and food insecurity (Sabates-Wheeler and Devereux, 2010).

A number of non-profit international development agencies have sought to address this crisis, among them Heifer International, a U.S.-based nongovernmental organization whose mission is "to work with communities to end hunger and poverty and care for the Earth" (http://www.heifer.org/ourwork/mission). During the organization's 60 years of operation, Heifer projects have reached millions of people spanning 128 countries through its signature livestock donation programs, complemented by training in livestock care, environmental protection, business development, leadership, and gender equality. The extensive track record and favorable public opinion of Heifer's - and other organizations' - animal donation programs notwithstanding, there has been no prior rigorous quantitative evaluation of these programs' performance that we or Heifer could identify. Given that animal donations are expensive Heifer (personal communication) reports that the average full cost of a pregnant cow, delivered to the Rwandan beneficiary households we study, is roughly $\$ 3,000$ - solid evidence of impact is arguably long overdue.

The research we report in this paper evaluates the impact of two of Heifer's animal donation programs in Rwanda, one that donates dairy cows, and one that donates meat goats. One cornerstone goal of the Heifer program is improving the nutritional outcomes of participating households. We therefore examine program impacts on household dietary diversity and on child nutritional attainment as determined by height-for-age, weight-forheight, and weight-for-age z-scores, which are indicators for stunting, wasting, and underweight, respectively.

Using several econometric models, this paper compares beneficiary households with households likewise targeted for animal donations but that have not yet received animals, and with households that were not approved to receive animals. The results show large and highly statistically significant increases in household dairy consumption and household meat consumption among dairy cow and meat goat recipients, respectively. Our findings also indicate that livestock donations positively impact child health and nutrition, as evidenced by anthropometric data. Donations of dairy cows have a significant correlation with improvement 
in height-for-age $z$-scores of children, but have no effect on weight-for-height $z$-scores, whereas donations of meat goats are significantly correlated with improved weight-for-height $z$-scores without affecting height-for-age $z$-scores. In some specifications, donations of meat goats as well as dairy cows are also correlated with improved weight-for-age $z$-scores.

\section{BACKGROUND}

Malnutrition results from a combination of an inadequate intake of calories, micronutrients, and/or high-quality protein (Black et al. 2008, Victora et al. 2008). Research increasingly demonstrates that animal-source foods provide complete protein, energy, and an array of micronutrients that are often limited or unavailable in the rural peasant diet (Scrimshaw, 1994). In addition to providing a good source of protein and calories, meat and milk products are an important source of calcium, selenium, iron, zinc, and vitamins A and B-12. Inadequate intake of these nutrients is associated with anemia, poor growth, rickets, impaired cognitive performance, blindness, and neuromuscular deficits. Even relatively small amounts of animalsource foods can substantially increase nutrient adequacy (Murphy and Allen, 2003). While there are other methods of obtaining these micronutrients, it is difficult to even approach meaningful levels of nutrients such as calcium and vitamin B-12 on a plant-based diet with a poverty-level income (Murphy, Beaton, and Calloway, 1992). Low incomes, in tandem with limited access to animals, often mean that poor households consume few animal-source foods. They are forced instead to rely on less expensive, imperfect substitutes, and their children suffer malnutrition (Neumann et al., 2002). In our setting, rural Rwanda, baseline livestock ownership and consumption of animal-source foods is very low. The Ministry of Agriculture and Animal Resources (2006) reports estimates that per capita monthly milk consumption is only around 12 liters, roughly half the rate in Uganda (22 liters) and one-eighth the rate in Kenya ( $\sim 100$ liters), although many Rwandans consume fermented milk products, making it difficult to accurately estimate the true consumption of dairy products.

In a review of the challenges facing child nutrition in sub-Saharan Africa, Lartey (2008) notes that early childhood malnutrition likely accounts for the high prevalence of stunting (height-for-age z-score $<-2$ ) and underweight (Weight-for-age z-score <-2) reported for children. In Africa, 40 percent of children younger than five years old are moderately or severely stunted (UNICEF, 2010). Many cross sectional studies of high-risk children have identified associations between stunting and cognitive ability. Compared with non-stunted children, stunted children are less likely to be enrolled in school, more likely to enroll late, more likely to attain lower achievement levels or grades for their age, and have poorer cognitive ability or achievement scores. Although there are fewer studies concerning younger 
children, several empirical connections have been established between child development measures and height-for-age $\mathrm{z}$-score, as well as weight-for-age z-score. For an overview of these findings, see Grantham-McGregor et al. (2007).

The earliest stages of life for children are both "sensitive," since the effects of experience during this time on neural and physical development are unusually strong, as well as "critical," since these effects are largely irreversible (Knudsen, 2004). In this vein, economic or environmental shocks early in life have been shown to affect future outcomes (Victora et al. 2008). A study of drought and civil war in the first two years of a child's life has shown an association with reduced child height and schooling (Alderman et al., 2006), while beneficial rains in the year of a girl's birth are associated with an increase in her adult height, years of schooling, and wealth (Maccini and Yang, 2009) and participation in an early childhood nutrition intervention is associated with increased adult educational attainment, body size and work capacity, as well as higher adult economic productivity and wages (Hoddinott et al. 2008, Maluccio et al. 2009, Martorell et al. 2010) .

For many of the poor in the developing world, livestock ownership offers a potential pathway out of poverty and malnutrition. In a household facing imperfect markets, there are various channels through which livestock ownership impacts the health and nutritional status of households. The following framework (adapted from Nicholson et al, 2003), presents the positive and negative implications of livestock ownership on health outcomes.

The direct health benefits of livestock ownership lie in the increased availability and consumption of animal-source foods, which provide essential nutrients and dietary diversity and mitigate seasonal fluctuations in food crop availability (Murphy and Allen, 2003; Wilson et al., 2005). Through sales of animal products, livestock ownership also increases household income, which can be used for the purchase of higher-quality healthcare and food thereby increasing nutrient availability to household members (Senauer, 1990; Kennedy, 1994). The gender pattern of income control affects a household's propensity to spend additional income on food and health related items (Thomas, 1997; Tangka et al., 2000), since female control of household resources is often associated with consumption preferences which favor basic needs and child welfare (Rogers, 1996). Because women and girls commonly bear husbandry responsibilities for lactating animals (and poultry), increased holdings of such livestock commonly gives women greater control over resources within the household (McPeak and Doss 2006). Additionally, livestock contribute to efficient nutrient cycling by increasing soil nutrient content and crop yields (Delve et al., 2001).

However, due to time and resource constraints, increasing livestock ownership may 
decrease the (financial and time) resources devoted to food crops, reducing production, consumption and sales. Unconfined livestock also commonly damage standing or stored crops. Animal keeping can also raise the incidence of zoonotic disease, either through direct transmission or contamination of food and/or water resources. By increasing labor demand, especially from the females of the household, animal ownership may decrease the time and quality of care for children (von Braun et al., 1994; Huffman, 1987).

The possibility of both positive and negative effects of transferring livestock to poor, rural households raises the natural question: what net impacts do animal donation programs have? To the best of our knowledge, there has been no prior, rigorous study on the net impact of livestock donations.

Extensive research has been done, however, regarding the impact of animal ownership on various health and nutritional outcomes. A number of studies on cattle ownership indicate positive nutritional benefits for children, particularly in East Africa. Intake of animal-source products has been shown to positively affect both physical and developmental outcomes in children, illustrating the potential utility of these foods in the diet (Neumann et al., 2002; Neumann and Harrison, 1994;). Hitchings (1982, cited by Nicholson, 2003) found a positive correlation between child height and the ownership of a milk cow, conditional on milk being used for family consumption. Leegwater et al. (1991) provide evidence that the nutritional status of pre-school children in the households participating in the National Dairy Development Project in Kenya was better than that of children from non-participating households. Vella et al. (1995) show that the ownership of a cow in rural Uganda is a significant predictor of child height-for-age z-score, while Grosse (1998, cited by Nicholson, 2003) finds that in rural Rwanda, an index of dairy animal ownership has a strong positive association with child height-for-age z-score.

In particular, in a recent paper whose results strongly paralleled those found in our own research, Hoddinott et al. (2013) find that cow ownership in rural Ethiopia is associated with increased milk consumption and reduced stunting in young children. Most interestingly, Hoddinott et al. find that the impact of cow ownership on child nutrition is strongest when households are more isolated from markets in which much of the milk would have the possibility of being sold. This lack of integration into local markets appears, in their research, to have positive spillovers on children's well-being, presumably due to increased consumption of animal-source foods.

\section{Data And Methodology}

Our data come from surveys of 406 households collected during the summer of 2011 in 
Rwanda, a small, densely populated country in East Africa. Heifer International has many ongoing projects in Rwanda, donating a wide variety of animals and providing various educational interventions. Our research team conducted surveys in two regions, one in which Heifer had initiated a dairy cow donation program and the other in which the organization had carried out widespread donation of meat goats. In the dairy cow region, Ruli (northern Rwanda), 224 households were surveyed. In this region, Heifer donates dairy cows to coffee farmers belonging to two distinct coffee cooperatives. The goal of the program is to increase dairy consumption and production in the region (as well as to increase coffee output via a fertilizer access program).

In order to qualify to receive a dairy cow, applicant households must meet a given set of requirements. The most stringent requirements are that households have at least one hectare of land, and they must commit to constructing a shed with a cement floor and metal roof to house the cow. (Once selected, Heifer provides loans to the beneficiaries to purchase building materials.) Households must not currently own a high-producing dairy cow, however, owning local-breed cows, which have much lower milk yields, is permissible. Note that eligible households are neither the poorest - who cannot afford to meet the program requirements nor the richest - who might already own the most productive livestock breeds available. This non-random eligibility necessitates paying close attention to selection criteria and to making a concerted effort to properly control for prospective ex ante differences between animal donation beneficiaries and non-beneficiaries in program evaluation since such differences could be correlated with differences in children's nutritional status.

Beyond these requirements, Heifer International was unable to provide a clear set of secondary selection criteria. According to Heifer International staff, beneficiaries are selected based on need as determined by a team of assessors. During the selection process, Heifer staff visit applicant households and review various household characteristics such as income, number of children, widow(er) status, etc. Upon selection, Heifer gives each beneficiary household an imported, pregnant cow. The imported cows produce a significantly greater amount of milk than the local cow breeds (up to 15 liters of milk per day after they give birth, as compared to just 0.5-1.0 liters for local breeds). Beneficiary households are required to give away the first female offspring of their cow as part of Heifer's "Pass on the Gift" initiative. If the offspring is a male (bull), beneficiaries may sell it for a considerable profit (approximately US \$250-\$1,000). Heifer International provides ongoing insemination services to beneficiaries so that the dairy cows may continue to produce milk and offspring. The sample for this research was chosen to include only recipients of first-generation imported dairy cows, not recipients of cows via the 
"Pass on the Gift" program.

In addition to the dairy cow program, an additional 182 surveys were collected from households in Heifer's meat goat region, Kirehe (eastern Rwanda). Kirehe is near the Tanzanian border, and is home to a large population of refugees who returned to Rwanda after the 1994 genocide. The area is much poorer overall than Ruli, with limited access to markets and less developed infrastructure. In Kirehe, the meat goat program is designed specifically as a poverty reduction tool and thus the participants are noticeably poorer than in Ruli. Researchers noted that Heifer's meat goat donation program is not as well organized or operated as the dairy cow program. While there is still an official requirement that beneficiaries build sheds to house the donated goats, the research team noticed many households where goats were tied to trees, or kept on concrete slabs with no roof. Upon selection into the program, each beneficiary household is given two female goats. A few beneficiaries in each area are also given a male goat to breed with the area's female goats. Heifer expects households to breed the goats for sale and/or consumption.

In both regions, the sample is divided into three groups. The first group consists of households that received an animal (dairy cow or meat goat, depending on the region) one year prior to the survey; we refer to members of this group as "Beneficiaries." The second group consists of households that applied to receive an animal and were approved to receive one in the near future (within a month following the survey); we call members of this group "Prospectives." The last group consists of households that applied to receive an animal in the upcoming cycle, but were excluded by Heifer during the screening process; this group we call "Nevers." For the purpose of this paper, the group “Qualified” includes both Beneficiaries and Prospectives - that is, all households in the sample that were qualified and selected to receive animals from Heifer International either the year prior to or at the time of data collection.

All households surveyed are similar in that they all expressed an interest in receiving an animal by applying to the livestock donation program. Thus, a household's program participation was determined by Heifer's eligibility criteria. We undertook substantial effort to ascertain why the Beneficiaries were given first priority to receive the animals among all qualified families out of concern for unobserved heterogeneity issues, but were never given satisfying answers to this question. It appears that in some cases the first round of donations were distributed to highly prioritized families, while in other cases the decision was made based on logistics. Unfortunately, this decision-making process was not systematic program-wide. To the extent that idiosyncratic factors related to first-round selection are orthogonal to impact variables, we are able to ascribe causality to our impact estimation results. We carry 
out robustness checks in our estimations to see how sensitive the significance of our results is to potential endogeneity related to the order of animal distribution. Poorer households with more malnourished children and limited access to animal-source foods may have been targeted for initial donations, so our estimates of program impact should, if anything, be biased against finding a favorable effect on dietary diversity and child nutrition outcomes.

Heifer staff provided lists of Beneficiaries, Prospectives, and Nevers in each region, and the team attempted to survey every listed household. If household members were not easily contacted, multiple efforts were made to reach them, including phoning friends and neighbors, and visiting houses multiple times to establish contact. In the event that the animal recipient or applicant was not present at the time of visit, the spouse or the eldest member of the household was interviewed.

The regressions we estimate take the general form:

$$
\Upsilon=\beta_{0}+\beta_{1}(\text { Qualified })+\beta_{2}(\text { Cow Beneficiary })+\beta_{3}(\text { Goat Beneficiary })+\beta_{4}(\text { North })+\boldsymbol{\gamma}^{\prime}(\text { Controls })+e_{i}
$$

where $\mathcal{Y}$ is a measure of nutritional outcomes, "Qualified" is a dummy variable indicating that the household either received an animal last year or will receive one soon (i.e., is either a Beneficiary or Prospective household). The estimated $\beta_{2}$ and $\beta_{3}$ coefficients measure the marginal effect of receiving a cow or goat, respectively, given that a household requested and qualified to receive an animal from Heifer International. The Qualified variable controls for any unobservable characteristics possessed by the Beneficiary and Prospective households that caused the Never households to be rejected for animal donation. The dummy variable "North" ensures that the households in the north and east regions are only compared to others within their region (e.g., cow Beneficiaries, cow Prospectives, and cow Nevers are compared to each other, but not to households in the goat region). This control is important as the regions vary greatly in terms of income, infrastructure, and climate, as well as in animal donation program design. The vector of controls used in the models include household characteristics and asset ownership (as well as child health characteristics, where appropriate). Variables for non-Heifer animal ownership are also included to be sure that the effect captured by the analyses is from receiving the Heifer animal specifically, and not picking up a general effect of animal ownership.

Table 1 presents the mean, standard deviation, minimum, and maximum values for each control variable included in our regressions. The average survey respondent in our sample is 46 years old, and has 4 years of education. The average respondent's household is made up of 5.5 members, and owns 0.7 hectares of land, 2 machetes, and 1 cell phone. The number of food groups consumed by respondents in the last two days ranged from 1 to 16 , with an average of 
6.63. Qualified households make up $80 \%$ of our sample, with $20 \%$ and $21 \%$ consisting of Goat and Cow beneficiaries, respectively.

\section{IMPACT ON DIETARY DIVERSITY}

Economic theory suggests that receiving a transfer will have an income effect that increases the number of food groups consumed overall by recipient households, because dietary diversity increases with income (Behrman and Deolalikar 1989). Abundant evidence also shows that when transfers are given in-kind, the induced marginal increases in consumption tend to concentrate disproportionately in the transferred good (Barrett 2002). This implies that in the case of dairy cow and meat goat donations, we would expect households to especially increase dairy and meat consumption, respectively, but perhaps also increase the number of food groups consumed overall by individuals.

Dietary information is notoriously difficult to gather using surveys. If given a lengthy reporting period, respondents often forget what they ate, or report what they think they eat on average during a normal week or month. To avoid these issues, respondents were given defined categories of food and asked how many times they ate foods in each category in the last two days. The survey questions both prompted the respondents to remember everything they ate, and limited the recall period for more accurate results. The survey questions were modified from the 2006 Demographic and Health Survey in Uganda. To measure the monthly consumption of dairy and meat per person in the household, respondents were asked how much milk or meat their household produces each month, how much is sold, and how much is consumed. The amount of total household consumption was then divided by the number of members in the respondent's household to establish the amount consumed per-person-month. If respondents did not know how much meat or milk was produced or consumed in a month, the information was recorded per week or per day and converted into a monthly figure upon entering the data.

\section{Individual Dietary Diversity}

Dietary diversity was measured by consumption within 16 dietary food groups from four major categories: staples, fruits and vegetables, starches, and other foods (Appendix A). We begin by testing for an effect of animal donations on the total number of food groups and on the number of non-dairy food groups consumed by the survey respondent in the last two days. Table 2 reports the Ordinary Least Squares (OLS) estimates of equation (1), with robust standard errors, with the number of food groups consumed by survey respondents in the last two days as the dependent variable. There appears to be no effect of meat goat donation on the 
number of food groups consumed. However, the coefficient on the variable for cow beneficiaries is positive and statistically significant at the 1 percent level, indicating that receiving a Heifer cow is highly correlated with an average increase of 1.17 food groups consumed in the last two days.

This effect appears to be exclusively driven by the respondents' consumption of dairy products, however. In the second regression in Table 2 , where the dairy food groups have been removed, there is no significant effect of being either a cow beneficiary or goat beneficiary on the number of food groups consumed. Dietary diversity appears to increase only via increased dairy consumption by beneficiaries of dairy cow donations. The variable "North" is positive and highly significant in both regressions which is unsurprising as, noted earlier, Ruli is a wealthier region overall than Kirehe. The coefficient estimates related to the various control variables such as land or phone ownership, when statistically significant, conform with expectations based on the pre-existing literature.

We estimate the effect of animal donation on dairy and meat consumption by the survey respondent in the last two days using Poisson regressions. These dependent variables are described by count data between zero and six, with a large number of observations censored at zero. Table 3 shows that cow beneficiaries consumed dairy an average of 1.2 more times in the last two days compared to the control groups. This effect is quite significant considering that the entire sample consumed dairy, on average, only 1.4 times in the last two days. The results also show that while wealth indicators, such as the number of cell phones or machetes or the amount of land owned by the household, are highly correlated with respondent meat consumption, we see no effect of being a goat beneficiary on meat consumption in the last two days. This may be because there is no effect, or possibly because meat is consumed too infrequently to be picked up by a dietary diversity measure based only on the last two days.

\section{Household Dairy Consumption}

To test whether animal donations affect household-level dairy and meat consumption, we use robust Tobit regressions. The Tobit model allows us to estimate the effect of the independent variables on the zero and positive values of the dependent variable separately, but reports a coefficient that is conveniently interpreted as a marginal effect.

Table 4 shows that household monthly per-person dairy consumption is positively correlated with being a cow beneficiary. Receiving a Heifer cow one year ago is associated with a statistically significant 9.34-liter increase in monthly per-person dairy consumption today compared to the control groups. This represents a nearly three-fold increase over the sample mean value of 3.6 liters per month. This likely partly reflects Rwandan households' propensity 
to consume ikivuguto, a yogurt-like substance made from fermented milk. This process reduces the volume of dairy so that what began as a liter of milk becomes less than 0.5 liters of yogurt. Not surprisingly, having a non-Heifer cow is also highly correlated with dairy consumption,

highlighting the importance of controlling for non-Heifer animal ownership. Interestingly, the impact coefficients of the Heifer and non-Heifer cows are roughly proportional to the milk yields of the two different breeds.

\section{Household Meat Consumption}

Table 4 also shows that being a Heifer meat goat recipient one year ago is correlated with an added monthly per-person meat consumption of 0.2 kilograms, although this result is significant at only the 10-percent level. This effect, however, would constitute a nearly 100percent increase above the sample mean of 0.27 kilograms of meat per-person per month. As above, households in the north consumed more meat regardless of beneficiary status. Also of note, owning pigs or sheep was significantly correlated with meat consumption.

\section{Household Dairy and Meat Consumption Using Propensity Score and Nearest Neighbor Matching}

As a check on the Tobit results just discussed, we estimated the average treatment effects on the treated using Propensity Score Matching (PSM) and Nearest Neighbor Matching (NNM) techniques. While PSM matches treated and untreated observations based on an estimated propensity for selection into treatment, NNM matches observations over a vector of covariates. Since every household in the sample expressed interest in receiving an animal, treatment was based on the fulfillment of Heifer criteria, which were largely based on observable household characteristics. Using variables that reflect these criteria to estimate the likelihood of selection into the animal donation program, we first estimate propensity scores for each household via probit estimation (Appendix B1). We then match treated households (Beneficiaries) with untreated but qualified households (Prospectives) based on their propensity scores to create "pre-" and “post-treatment” groups among our sample of Qualified households. The variables that we match over (age, education, household size, log land size, female head of house [dummy], number of females in the house younger than 21 , number of males in the house younger than 21) pre-date application to or selection into treatment, so that we avoid matching over potentially endogenous variables that could be altered by receipt of the animal. The mean difference between matched treated and untreated households represents the estimated average treatment effect on the treated. Matching is carried out separately for the northern and eastern sub-samples to make sure that an observation from the north region is not matched to an observation from the east region. 
Due to a limited sample size, the PSM probit is estimated on a select few control variables. After running the PSM models, balancing tests verify that there is no statistically significant difference between the means of matched pairs. In order to account for the fact that the PSM variance of treatment effect does not include the variance due to estimation of the propensity scores, imputation of common support, and possibly also the order in which treated individuals are matched (Caliendo and Kopeinig, 2005), we also bootstrap standard errors, reestimating the results starting from the first step of propensity score estimation with 1000 bootstrap replications.

As seen in Table 5, the PSM results for dairy consumption are quite similar to the results found using Tobit estimation. We find that receiving a dairy cow has an average treatment effect on the treated (ATT) of 10.91, meaning that in Beneficiary households, members on average consumed 10.91 more liters of milk per month than members of Prospective households. With a standard error of 1.41, the result is significant at the one percent level. This is statistically indistinguishable from the 9.34 liters estimate above.

As a check on our PSM results, we carry out a Nearest Neighbor Matching (NNM) in which observations are matched not on propensity score, but on a weighted Euclidean distance over a set of matching variables (Abadie and Imbens, 2006; Abadie et al., 2004). Some researchers favor NNM over PSM because the estimator is nonparametric and relies on analytical standard errors rather than bootstrapped standard errors. Using NNM on a set of matching covariates that predate program participation yields very similar estimates. We find an average treatment effect of 10.23 liters per person, per month with a standard error of only 1.73, statistically insignificantly different from the Tobit and PSM estimates.

Since matching estimators are not robust to the presence of unobserved characteristics that influence both assignment into treatment and the outcome (Rosenbaum, 2002), we estimate Rosenbaum bounds to determine the extent to which the significance of the results relies on the untestable conditional independence assumption (Becker and Caliendo, 2007). Rosenbaum bounds measure how confounded treatment selection would have to be under the worst-case scenario (of endogeneity bias) for causal effects from a matching analysis to lose their significance (DiPrete and Gangl, 2004). In other words, Rosenbaum bounds measure how strongly an unobserved variable that is correlated with both treatment and the outcome variable would need to affect selection into treatment in order to invalidate the results. The Rosenbaum bounds output gives a threshold value, $\Gamma$, which represents the threshold effect of unobserved covariates on the odds ratio of treatment at which the significance of the result becomes statistically questionable. 
The Rosenbaum bounds test on the dairy consumption PSM results suggests that significance at the 5-percent level is only invalidated at a $\Gamma$ of 9.5 (Table 5). This means that if there is an unobservable characteristic that causes the odds ratio of self-selection to be 9.5 times higher for those who were eventually treated, and the characteristic nearly perfectly predicts dairy consumption, the results would no longer be valid at the five percent level. While there is no hard-and-fast rule on what $\Gamma$ threshold is acceptable for ruling out endogeneity as the cause of statistical significance, it seems highly unlikely that selection based on unobservables into dairy cow treatment could be biased to this degree as to invalidate this result.

Table 5 also shows the PSM and NNM results for goat donation on meat consumption. The PSM estimated average treatment effect on the treated indicates that being a goat recipient is correlated with increased per-person monthly meat consumption of 0.11 kilograms, although the result is not statistically significant. The ATT of 0.11 is statistically insignificantly different from the estimated effect of 0.20 kilograms found in the prior Tobit regression without matching. Similarly, using NNM we find an average treatment effect of 0.17 kilograms per person, per month, which is statistically significant at the 10 percent level and not statistically significantly different from the PSM or Tobit estimates.

The Rosenbaum bounds test on the meat consumption PSM results yield a critical level of $\Gamma$ of 1, indicating that the results are highly sensitive to potential selection on unobservables. So we regard our impact estimates on meat consumption with less confidence than our dairy impact estimates.

\section{IMPACT ON ChILd Nutritional Status}

The nutritional status of children under the age of five years ${ }^{1}$ provides a good reflection of the nutritional well-being of developing countries, since children are the most vulnerable to the problems arising from inadequate food intake and disease. Because insults to child nutritional status tend to persist and are thus strongly correlated with adult stature, which is itself strongly correlated with adult earnings, child nutritional status also offers an important leading indicator of economic productivity in subsequent years (Victora et al. 2008).

Anthropometric measurements of weight and height, as well as data on sex and age,

\footnotetext{
${ }^{1}$ Infants typically do not directly consume dairy products, much less meat, so if one were interested exclusively in the effect of animal donation on child nutrition due solely to direct consumption of animal source foods, it might be appropriate to restrict the subsample to children older than six months. Because we are interested in the net effects of animal donation, however, which includes effects mediated through the nutrition of breastfeeding mothers, hygiene within the household - which can be affected by the presence of livestock and perishable products in the absence of refrigeration - income effects due to animal ownership, time spent on childcare, etc., we include all children under five years of age. The relatively small size of our sample of children also favors this more inclusive approach for practical, statistical reasons.
} 
provide the basic information needed to assess a child's nutritional status (Quinn, 1992). Nutritional status is often measured as the ratios of height-for-age, weight-for-age, and weightfor-height. These measures are converted to z-scores, the number of standard deviations from a reference population conditional on age and sex, as outlined by the World Health Organization's global child growth reference standards (http://www.who.int/childgrowth/en/), where $z \geq-1.0$ is normal, $-1.0>z \geq-2.0$ is mild malnutrition, $-2.0>z \geq-3.0$ is moderate malnutrition, and $z<-3.0$ is severe malnutrition. Wasting is defined as having a weight-for-height $z$-score (WHZ) less than -2 and is indicative of acute malnutrition, i.e. short-term deficiencies such as illness or severe food shortages. Chronic malnutrition, or stunting (defined as height-for-age z-score [HAZ] $<-2$ ) is more common than acute malnutrition and reflects past shortages of food intake and recurring bouts of illness. Being underweight is defined as a weight-for-age z-score (WAZ) less than -2 and indicates that a child is affected by chronic and/or acute malnutrition. It is important to note that a higher z-score is interpreted as a lower degree of malnutrition and vice versa. The standardized $z$-scores can be compared between age groups as well as between indicators of malnourishment.

We estimate the effect of animal donations on these measures of nutritional status for individual children ages 0-60 months old. The sample is composed of 99 children in the north and 129 children in the east region, 43 and 62 of whom are from beneficiary households that have received a dairy cow or a meat goat, respectively. The distribution of $z$-scores less than -2 in the sample indicates the prevalence of malnutrition. As shown in Table 6a, a majority of sample children are at least mildly stunted $(\mathrm{HAZ}<-1)$. But underweight and wasting are far less frequent; indeed, in the northern subsample, there was no moderate or severe wasting, reflecting the fact that recent harvests had been good and economic growth over the past year quite robust in Rwanda. The sample prevalence of moderate and severe malnutrition reasonably closely mimics the Rwandan national pattern, as seen in Table $6 \mathrm{~b}$.

We estimate the effect of dairy cow and meat goat donations on individual child nutritional status using a Seemingly Unrelated Regressions (SUR) estimator which allows error terms to be correlated across indicators. The variables used in the regression analysis are described in Table $1 \mathrm{~b}$. We compare the SUR results with a matching estimation using NNM and PSM. Due to the limited sample size of children, the matching estimation is an imprecise approach, and thus used only as a robustness check.

We estimate equation (1) including a range of control variables. Child-specific characteristics include age (linear and quadratic), sex, and birth order, which have been found 
to be significant determinants of nutritional and health status (Nicholson et al, 2003). Child health controls, including questions reflecting breastfeeding, hospitalization, incidence of diarrhea, and milk consumption, were adapted from the Demographic and Health Survey of Rwanda. Household characteristics contain information about the education level of household head, mother's age, whether it is a female-headed household, and household size. Finally, asset ownership such as the building material of the house, the household's access to water from a pipe inside the home or a communal well/tap, as well as number of mobile phones compose a rough wealth index to control for the effects of income on child nutrition.

\section{Estimation Results}

Table 7 shows the SUR estimation results. Donations of dairy cows show a positive and statistically significant (at the 10-percent level) effect on the mean height-for-age $z$-score for children, consistent with the results of Vella (1995) and Grosse (1998). The magnitude of 0.54 standard deviations is greater than the effects of dairy cow ownership reported by Vella (1995). It is also greater than the effects reported by Nicholson et al. (2003) in the highlands sample (0.29 to 0.35 standard deviations), but similar to the effects in the coast sample which ranged from 0.60 to 1.12 standard deviations in SUR and random effects models, respectively. Our estimated impacts on HAZ are also only slightly larger than the results of Hoddinott et al. (2013), which show that household ownership of just a single cow in their Ethiopian study predicts an increase in HAZ of between 0.25 and 0.47 standard deviations. However, dairy cow donations do not show a significant effect on weight-for-height $z$-scores or weight-for-age $z$ scores (magnitudes of -0.05 and 0.40 respectively, both insignificant at any standard confidence level). The effect on HAZ could be interpreted as an indication of the role of dairy cattle as a long-term nutritional solution, consistent with the findings of Hitchings (1982).

In the case of meat goat donations, we do not observe a statistically significant effect on height-for-age z-scores. However, meat goat donations are found to have a statistically significant and positive impact on WHZ of 0.47 standard deviations. This is consistent with the idea that the increased household consumption of meat arising from meat goat donations improves a child's nutritional status in the short-term due to the increased uptake of animalsource foods. However, this result begs further analysis since previous literature does not show a link between non-dairy and/or small livestock and improved nutritional status (Vella et al., 1995; Annan, 1985, cited by Nicholson et al., 2003).

Lastly, the estimation results show that both meat goat and dairy cow donations are associated with increased WAZ, by 0.42 and 0.40 standard deviations, respectively (significant 
at the $10 \%$ level for meat goats and marginally insignificant for dairy cows at the $12 \%$ level). Since being underweight $(\mathrm{WAZ}<-2)$ signifies a combination of chronic and acute malnutrition, it is not surprising that increased consumption of animal-source foods either from meat goats or dairy cows alleviates acute or chronic malnourishment, respectively, and improves weightfor-age z-score measures.

In models presented in Table 7, being selected into program participation (i.e., either as a beneficiary or a prospective beneficiary) was found to hold an inverse relationship with all outcome measures. Regional effects are a significant predictor of height-for-age z-score, which is not surprising given the lower mean HAZ in the northern region. Age was found to be negatively related to all three outcome measures (and in most cases significant), albeit at a decreasing rate, as is typical in the literature. Longer periods of breastfeeding correspond to higher HAZ and WAZ, while a higher incidence of diarrhea is negatively correlated with all outcomes. The number of times a child has visited the hospital in the last month is positively related to $\mathrm{HAZ}$ and $\mathrm{WAZ}$ indicators; it is possible that rather than indicating poor child health, this variable instead serves as a gauge of household wealth, health education, and/or maternal care practices.

\section{Results from Propensity Score and Nearest Neighbor Matching}

PSM and NNM estimation are run as a robustness check on the SUR analysis. Children from Beneficiary households are matched to children from Prospective households (matching is carried out separately for each region). The chosen PSM specification is one-to-one nearest neighbor matching with replacement. The focus of this specification is to reduce bias, rather than solicit better hypothesis testing through lower variance. Given the small sample size we do not expect statistically significant coefficient estimates; however, we attempt to reduce bias in order to check on the magnitude of the estimated SUR coefficients. Selection into treatment is estimated using a Probit estimator (Appendix B2). While each estimation is on common support, balancing tests show that not all variables are balanced between treatment and comparison.

Both PSM and NNM estimations do not produce significant results and the point estimates are inconsistent with the SUR estimate (coefficient estimates are shown in Table 8). This may be a consequence of the small sample size as well as an indication of a problematic model of selection into treatment (Appendix B2 shows the low classification rates of Probit post-estimation).

The lack of concrete statistical significance across all the models may be due to other factors besides small sample size. Specifically, some subjects did not know the precise date of 
birth of their children, which is necessary in correctly computing anthropometric z-scores. While this issue was treated in accordance with the prescription outlined by Quinn (1992) for conducting child nutritional surveys in developing countries, measurement error is still likely.

Nevertheless, our results point to a likely existence of a causal effect of livestock donations on improved child anthropometrics although the magnitude of the impact is not yet concretely quantifiable. While our estimations are indicative of positive impact on anthropometric measures, they invite further research with larger sample sizes to more precisely gauge the impact of animal donation on children's health and establish the external validity of our results.

\section{CONCLUSIONS}

The results of our research on the impact of livestock donations are encouraging for organizations looking to increase consumption of nutrient-rich animal-source foods and to improve household dietary diversity and child nutritional status in developing countries. More precisely, we find that the Rwandan households that received a dairy cow increased monthly dairy consumption by 9.34 liters per person, while families that received a donated meat goat increased monthly meat consumption by 0.20 kilograms per person, all relative to otherwise similar households that had not yet received a donated animal. Children under five years of age in households that received a dairy cow enjoyed a statistically significant gain in height-for-age z-score of 0.54 standard deviations, on average, and a statistically insignificant gain in weightfor-age z-score of 0.40 standard deviations. Donations of meat goats had a statistically significant effect of 0.47 standard deviations on child weight-for-age z-score and 0.42 standard deviations on weight-for-height z-score, but a much smaller and statistically insignificant 0.1 standard deviation effect on child height-for-age z-score.

This analysis underscores the role of livestock in improving diets and child nutritional status among poor rural families in the developing world. The promise evident in animal donation programs is apparent, even if the impacts remain difficult to estimate precisely in small, observational studies such as ours. The magnitude of our dairy results may seem remarkable; but our results parallel closely the recent findings of Hoddinott et al. (2013), who find impacts on stunting within a similar range from dairy cow ownership, and where the impact on children from households isolated from dairy markets is greater. Indeed, it appears that when missing markets prevent households from trading dairy cow milk, a much greater share of milk production is consumed by the household, and often given to children, to their nutritional benefit. 
A follow-up study using a randomized control trial design with long-term tracking to establish the sustained nutritional, health and other effects of livestock donations would enrich our understanding of how such programs affect dietary diversity, child and adult nutritional outcomes, and longer-term development results in developing countries, as well as the pathways through which such impacts are realized. This type of research carries important policy implications, not only for international programs like those of Heifer International, but also for local livestock intensification programs that focus on the role of livestock in rural households. 


\section{REFERENCES}

Abadie, A. and G. Imbens. 2006. Large sample properties of matching estimators for average treatment effects. Econometrica 74 (1): 235267.

Abadie, A., Drukker, J., Herr, L. and Imbens, G. (2004) Implementing matching estimators for average treatment effects in Stata. Stata Journal, 4(3), pp. 290-311.

Alderman, H., J. Hoddinott, and B. Kinsey. 2006. Long term consequences of early childhood malnutrition. Oxford Bulletin of Economics and Statistics, 58(4), 450-474.

Annan, A. 1985. The Socioeconomic Determinants of Malnutrition Among Preschool Children in Ghana. Ph.D. Dissertation, Cornell University.

Barrett, C. B. 2002. Food security and food assistance programmes. In Gardner, B. and Rausser, G. (eds.), Handbook of Agricultural Economics. Amsterdam: Elsevier Science.

Becker, S., and M. Caliendo. 2007. Sensitivity analysis for average treatment effects. Stata Journal, 7, Number 1: 71-83.

Behrman, J., and A. Deolalikar. 1989. Is Variety the Spice of Life? Implications for Calorie Intake. Review of Economics and Statistics, vol. 71, no. 4, pp. 666-672.

Behrman, J., Hoddinott, J., Maluccio, J., Quisumbing, A., Martorell, R., and A. Stein. 2003. The impact of experimental nutritional interventions on education into adulthood in rural Guatemala: Preliminary longitudinal analysis. Philadelphia, PA: University of Pennsylvania, Washington, DC: International Food Policy Research Institute, and Atlanta, GA: Emory University.

Black, R.E., L.H. Allen, Z.A. Bhutta, L.E.Caulfield, M. de Onis, M. Essati, C. Mathers, and J. Rivera. 2008. Maternal and child undernutrition: global and regional exposures and health consequences. Lancet, (371): 243-260.

Caliendo, Marco \& S. Kopeinig. 2005. Some practical guidance for the implementation of Propensity Score Matching. Institute for the Study of Labor Discussion Paper No. 1588.

Delve, R. J., Cadisch, G., Tanner, J. C., Thorpe, W. Thorne, P. and Giller, K. E. 2001. Implications of Livestock Feeding Management on Soil Fertility in the Smallholder Farming Systems of Sub-Saharan Africa. Agriculture Ecosystems and Environment, 84, 227-243.

DiPrete, T. A. and Gangl, M. 2004. Assessing Bias in the Estimation of Causal Effects: Rosenbaum Bounds on Matching Estimators and Instrumental Variables Estimation with Imperfect Instruments. Sociological Methodology, 34: 271-310.

FAO, The State of Food Insecurity in the World 2012, accessed 12 November 2012 at http://www.fao.org/publications/sofi/en/.

Grantham-McGregor, S., Y. B. Cheung, S. Cueto, P. Glewwe, L. Richter, B. Strupp, and the International Child Development Steering Group. 2007. Child development in developing countries 1: Developmental potential in the first 5 years for children in developing countries. Lancet, 369, 60-70. 
Grosse, S. D. 1998. Farm Animals and Children's Nutritional Status in Rural Rwanda. Presentation at the Symposium on Human Nutrition and Livestock, October 14, 1998, Little Rock, Arkansas: Heifer Project International.

Hitchings, J.A. 1982. Agricultural Determinants of Nutritional Status Among Kenyan Children. PhD. Dissertation, Stanford University.

Hoddinott, J., J. Maluccio, J. R. Behrman, R. Flores, and R. Martorell. 2008. Effect of a Nutrition Intervention during Early Childhood on Economic Productivity in Guatemalan Adults. Lancet 371 (9610): 411-416.

Hoddinott, J., D. Headey, and M. Dereje. 2013. Cows, missing milk markets and nutrition in rural Ethiopia. Presentation at the Farm production and nutrition workshop, World Bank, June 7, 2013.

Huffman, S. L. 1987. Women's Activities and Impacts on Child Nutrition, in Food Policy: Integrating Supply, Distribution, and Consumption, J. P. Gittinger, J. Leslie, and C. Hosington, eds. Baltimore: The Johns Hopkins University Press. [EDI Series in Economic Development]

Knudsen, E. I. 2004. Sensitive Periods in the Development of the Brain and Behavior. Journal of Cognitive Neuroscience, 16(8), 1412-1425.

Kennedy, E. 1994. Health and Nutrition Effects of Commercialization of Agriculture, in Agricultural Commercialization, Economic Development, and Nutrition, J. Von Braun and E. Kennedy, eds. Baltimore: The Johns Hopkins University Press.

Lartey, Anna. 2008. Maternal and child nutrition in Sub-Saharan Africa: challenges and interventions. Proceedings of the Nutrition Society, 67, 105-108.

Leegwater, P., Ngolo, J. and Hoorweg, J. 1991. Dairy Development and Nutrition in Kilifi District, Kenya. Food and Nutrition Studies Programme, Report No. 35. Nairobi, Kenya: Food and Nutrition Planning Unit, Ministry of Planning and National Development; Leiden, Netherlands: African Studies Center.

Maccini, S., and D. Yang. 2009. Under the Weather: Health, Schooling, and Economic Consequences of Early-Life Rainfall. American Economic Review, 99(3), 1006-1026.

Maluccio, J. A., J. Hoddinott, J. Behrman, R. Martorell, A. Quisumbing, and A. Stein. 2009. The impact of Nutrition During Early Childhood on Education among Guatemalan Adults. Economic Journal 119 (April): 734-763.

Martorell, R., P. Melgar, J.A. Maluccio, A.D. Stein and J.A. Rivera. 2010. The Nutrition Intervention Improved Adult Human Capital and Economic Productivity. Journal of Nutrition 140 (2): 411414. 
McPeak, J., and C. Doss. 2006. Are Household Production Decisions Cooperative? Evidence on Pastoral Migration and Milk Sales from Northern Kenya. American Journal of Agricultural Economics 88 (3):525-541.

Murphy S. P., Beaton G. H., and D. H. Calloway. 1992. Estimated Mineral Intakes of Toddlers: Predicted Prevalence of Inadequacy in Village Populations in Egypt, Kenya, and Mexico. American Journal of Clinical Nutrition, 56:565-572.

Murphy, S. P., and L. H. Allen. 2003. Nutritional importance of animal source foods. Journal of Nutrition, 133(11S-II):3932S-3935S.

Neumann C. G., Harris D. M., and Rogers L. M. 2002. Contribution of animal source foods in improving diet quality and function in children in the developing world. Nutrition Research, 22: 193-220.

Neumann C. G., and G. Harrison. 1994. Onset and Evolution of Stunting in Infants and Children. Examples From the Human Nutrition Collaborative Research Support Program, Kenya and Egypt Studies. European Journal of Clinical Nutrition, 48 Suppl 1: S90-102.

Nicholson, C. F., Mwangi, L., Staal, S.J., and P. K. Thornton. 2003. Dairy Cow Ownership and Child Nutrition Status in Kenya. AAEA Meetings Selected Paper.

Quinn, V.J. 1992. A User's Manual for Conducting Child Nutrition Surveys in Developing Countries. Cornell Food and Nutrition Policy Program, Cornell University. [Working Paper 21]

Rogers, B. 1996. The Implications of Female Household Headship For Food Consumption and Nutritional Status in The Dominican Republic. World Development, Vol. 24, No. 1, pp. 113-128.

Rosenbaum, P. R. 2002. Observational Studies. 2nd ed. New York: Springer.

Sabates-Wheeler, R., and S. Devereux. 2010. Cash transfers and high food prices: Explaining outcomes on Ethiopia’s Productive Safety Net Programme. Food Policy, 35.4: 274-285.

Scrimshaw N. 1994. The Consequences of Hidden Hunger for Individuals and Societies. Food and Nutrition, 15: 3-23.

Senauer, B. 1990. Household Behaviour and Nutrition in Developing Countries. Food Policy, 15(5):408-417.

Tangka, F. K., M. A. Jabbar and B. I. Shapiro. 2000. Gender Roles and Child Nutrition in Livestock Production Systems in Developing Countries: A Critical Review. Nairobi, Kenya: International Livestock Research Institute. [Socio-economics and Policy Research Working Paper 27]

Thomas, D. 1997. Incomes, Expenditures, and Health Outcomes: Evidence on Intrahousehold Resource Allocation, in Intrahousebold Resource Allocation in Developing Countries: Models, Methods, and Policy, L. Haddad, J. Hoddinott, and H. Alderman, eds. Baltimore: Johns Hopkins University Press. 
UNICEF State of the World's Children. Special Edition on Children’s Rights. 2010.

Vella, V., A. Tomkins, J. Nviku, and T. Marshall. 1995. Determinants of Nutritional Status in Southwest Uganda. Journal of Tropical Pediatrics, 41(2):89-98.

Victoria C. et al. 2008. Maternal and Child Undernutrition: consequences for adult health and human capital. The Lancet, Vol. 371: 340-57.

Von Braun, J. H. Bouis, and E. Kennedy. 1994. Conceptual Framework, in Agricultural Commercialization, Economic Development, and Nutrition, J. Von Braun and E. Kennedy, eds. Baltimore: Johns Hopkins University Press.

Wilson, T., A. Pearson, N. Bradbear, A. Jayasuriya, H. Laswai, L. Mtenga, S. Richards, and R. Smith. 2005. Livestock products-Valuable and more valuable. Pages 109-126 in Livestock and Wealth Creation: Improving the Husbandry of Animals Keptby Resource-Poor People in Developing Countries. E. A. Owen, A. Kitalyi, N. Jayasuriya, and T. Smith. ed. Nottingham Univ. Press, Nottingham, UK.

World Health Organization Nutrition Landscape Information System, Country Profile: Rwanda (2010-11). Accessed at: http://apps.who.int/nutrition/landscape/report.aspx?iso=rwa 
Table 1a: Description of Variables, By Region (Whole Sample)

\begin{tabular}{|c|c|c|c|c|c|}
\hline \multirow[t]{2}{*}{ Variable } & \multirow[t]{2}{*}{ Description } & \multicolumn{2}{|c|}{ North } & \multicolumn{2}{|c|}{ East } \\
\hline & & Mean & Std. Dev. & Mean & $\begin{array}{l}\text { Std. } \\
\text { Dev. }\end{array}$ \\
\hline $\begin{array}{l}\text { Cow } \\
\text { Beneficiary }\end{array}$ & $\begin{array}{l}\text { Dummy indicating that the household received } \\
\text { a cow one year ago }\end{array}$ & 0.39 & 0.49 & 0.00 & 0.00 \\
\hline $\begin{array}{l}\text { Goat } \\
\text { Beneficiary }\end{array}$ & $\begin{array}{l}\text { Dummy indicating that the household received } \\
\text { a goat one year ago }\end{array}$ & 0.00 & 0.00 & 0.46 & 0.50 \\
\hline Qualified & $\begin{array}{l}\text { Dummy indicating that the household is either } \\
\text { a beneficiary or prospective }\end{array}$ & 0.82 & 0.38 & 0.77 & 0.42 \\
\hline $\begin{array}{l}\text { Non-Heifer } \\
\text { Cow }\end{array}$ & $\begin{array}{l}\text { Number of non-Heifer cows a household } \\
\text { currently has (includes Heifer offspring) }\end{array}$ & 0.60 & 0.92 & 0.09 & 0.34 \\
\hline $\begin{array}{l}\text { Non-Heifer } \\
\text { Goat }\end{array}$ & $\begin{array}{l}\text { Number of non-Heifer goats a household } \\
\text { currently has (includes Heifer offspring) }\end{array}$ & 1.29 & 1.43 & 1.17 & 1.66 \\
\hline North & $\begin{array}{l}\text { Dummy variable for location; }=1 \text { if household } \\
\text { is in the dairy cow zone (Ruli); =0 if the } \\
\text { household is in the meat goat zone (Kirehe) }\end{array}$ & 1.00 & 0.00 & 0.00 & 0.00 \\
\hline \multicolumn{6}{|c|}{ Dietary Diversity } \\
\hline Groups & $\begin{array}{l}\text { Number of food groups consumed by the } \\
\text { respondent in the last two days (out of } 16 \text { ) }\end{array}$ & 7.79 & 2.72 & 5.21 & 2.21 \\
\hline $\begin{array}{l}\text { Groups, Non- } \\
\text { dairy }\end{array}$ & $\begin{array}{l}\text { Number of non-dairy food groups consumed by } \\
\text { the respondent in the last two days (out of 14) }\end{array}$ & 7.04 & 2.28 & 4.91 & 1.98 \\
\hline Ind. Dairy & $\begin{array}{l}\text { Number of times milk or yogurt was consumed } \\
\text { by the respondent in the last two days }\end{array}$ & 1.07 & 1.56 & 0.40 & 1.04 \\
\hline Ind. Meat & $\begin{array}{l}\text { Number of times meat was consumed by the } \\
\text { respondent in the last two days }\end{array}$ & 0.51 & 0.87 & 0.26 & 0.73 \\
\hline PPMeat & $\begin{array}{l}\text { Kilograms of meat consumed by the household } \\
\text { per person per month }\end{array}$ & 0.30 & 0.51 & 0.23 & 0.44 \\
\hline PPDairy & $\begin{array}{l}\text { Liters of dairy (milk and yogurt) consumed by } \\
\text { the household per person per month }\end{array}$ & 5.79 & 8.78 & 1.17 & 2.70 \\
\hline \multicolumn{6}{|c|}{ Household Characteristics \& Asset Ownership } \\
\hline Household Size & Number of persons in household & 6.11 & 2.00 & 4.89 & 1.75 \\
\hline Age & Age (years) of household head (respondent) & 49.76 & 11.25 & 40.66 & 13.61 \\
\hline $\begin{array}{l}\text { Female head of } \\
\text { house }\end{array}$ & $\begin{array}{l}\text { Household has a female aged } 16-65 \text { and no } \\
\text { male aged } 16-65\end{array}$ & 0.16 & 0.37 & 0.11 & 0.31 \\
\hline Female $<21$ & $\begin{array}{l}\text { Number of women in the household under age } \\
21\end{array}$ & 1.54 & 1.30 & 1.50 & 1.25 \\
\hline Male $<21$ & Number of men in the household under age 21 & 1.36 & 1.07 & 1.53 & 1.25 \\
\hline Land Size & Amount of land owned by household (hectares) & 1.61 & 1.34 & 0.69 & 0.59 \\
\hline Phones & Number of cell phones owned by household & 1.06 & 1.00 & 0.47 & 0.67 \\
\hline Education & Respondent's level of education (in years) & 4.62 & 3.82 & 3.70 & 3.14 \\
\hline Labor & $\begin{array}{l}\text { Amount spent on hired labor (thousands of } \\
\text { Francs/month) }\end{array}$ & 4707.99 & 11683.79 & 3944.03 & 13056.80 \\
\hline Machetes & Number of machetes owned by the household & 2.30 & 0.68 & 1.30 & 0.70 \\
\hline Beef & Number of beef cattle owned by the household & 0.14 & 0.43 & 0.03 & 0.32 \\
\hline Bull & Number of bulls owned by the household & 0.21 & 0.44 & 0.02 & 0.15 \\
\hline Pigs & Number of pigs owned by the household & 0.38 & 0.89 & 0.14 & 0.80 \\
\hline Sheep & Number of sheep owned by the household & 0.46 & 1.11 & 0.03 & 0.25 \\
\hline Chickens & Number of chickens owned by the household & 1.63 & 7.50 & 0.62 & 1.83 \\
\hline Rabbits & Number of rabbits owned by the household & 0.89 & 1.73 & 0.03 & 0.23 \\
\hline Observations & & & 94 & & \\
\hline
\end{tabular}




\section{Table 1b: Description of Variables, by Region (Sample: Households with Children 0-5 Years Old)}

\begin{tabular}{|c|c|c|c|c|c|}
\hline \multicolumn{2}{|l|}{ Variable } & \multicolumn{2}{|c|}{ North } & \multicolumn{2}{|c|}{ East } \\
\hline & & Mean & Std. Dev. & Mean & Std. Dev. \\
\hline $\begin{array}{l}\text { Cow Beneficiary } \\
(1=\text { Yes, } 0=\text { No })\end{array}$ & $\begin{array}{l}\text { Dummy indicating that the household } \\
\text { received a cow one year ago }\end{array}$ & 0.43 & 0.50 & 0.00 & 0.00 \\
\hline $\begin{array}{l}\text { Goat Beneficiary } \\
(1=\text { Yes, } O=\text { No })\end{array}$ & $\begin{array}{l}\text { Dummy indicating that the household } \\
\text { received a goat one year ago }\end{array}$ & 0.00 & 0.00 & 0.48 & 0.50 \\
\hline $\begin{array}{l}\text { Qualified }(1=\text { Yes, } \\
\mathrm{O}=\mathrm{No})\end{array}$ & $\begin{array}{l}\text { Dummy indicating that the household } \\
\text { either received an animal or will receive } \\
\text { one soon (beneficiary or prospective) }\end{array}$ & 0.86 & 0.35 & 0.80 & 0.40 \\
\hline $\begin{array}{l}\text { NonHeifer Cow } \\
\text { (number) }\end{array}$ & $\begin{array}{l}\text { Number of non-Heifer cows a household } \\
\text { currently has (includes Heifer offspring) }\end{array}$ & 0.68 & 0.82 & 0.12 & 0.39 \\
\hline $\begin{array}{l}\text { NonHeifer Goat } \\
\text { (number) }\end{array}$ & $\begin{array}{l}\text { Number of non-Heifer goats a household } \\
\text { currently has (includes Heifer offspring) }\end{array}$ & 1.41 & 1.41 & 1.04 & 1.82 \\
\hline $\begin{array}{l}\text { Region dummy } \\
(1=\text { North, } 0=\text { East })\end{array}$ & $\begin{array}{l}\text { Dummy variable for location; }=1 \text { if } \\
\text { household is in the dairy cow zone (North), } \\
=0 \text { if the household is in the meat goat } \\
\text { zone (East) }\end{array}$ & 1 & o & o & o \\
\hline \multicolumn{6}{|c|}{ Child Characteristics } \\
\hline HAZ & Height-for-age z-score & -1.28 & 1.30 & -1.01 & 1.51 \\
\hline WHZ & Weight-for-height z-score & 0.27 & 1.00 & 0.17 & 1.08 \\
\hline WAZ & Weight-for-age z-score & -0.72 & 1.07 & -0.62 & 1.22 \\
\hline Age (months) & Age of child, in months & 34.20 & 16.83 & 28.68 & 16.34 \\
\hline Sex & Sex of child ( $1=$ Male, $2=$ Female $)$ & 0.55 & 0.50 & 0.57 & 0.50 \\
\hline Birth order & Relative birth order of child & 1.18 & 0.41 & 1.24 & 0.45 \\
\hline \multicolumn{6}{|c|}{ Health Characteristics } \\
\hline $\begin{array}{l}\text { Age Stopped } \\
\text { Breastfeeding } \\
\text { (months) }\end{array}$ & $\begin{array}{l}\text { Age at which child discontinued any } \\
\text { breastfeeding, in months }\end{array}$ & 26.89 & 13.30 & 20.03 & 11.89 \\
\hline $\begin{array}{l}\text { Hospital Visits Last } \\
\text { Month }\end{array}$ & $\begin{array}{l}\text { Number of child hospital visits in the last } \\
\text { month }\end{array}$ & 1.82 & 0.56 & 1.88 & 0.32 \\
\hline $\begin{array}{l}\text { Incidence of diarrhea } \\
\text { last } 2 \text { weeks }\end{array}$ & $\begin{array}{l}\text { Number of times child had diarrhea in the } \\
\text { last two weeks }\end{array}$ & 0.52 & 1.70 & 1.68 & 3.17 \\
\hline $\begin{array}{l}\text { Times given animal } \\
\text { milk last } 2 \text { days }\end{array}$ & $\begin{array}{l}\text { Number of times child was given animal } \\
\text { milk in the last two days }\end{array}$ & 1.95 & 2.50 & 0.90 & 2.24 \\
\hline \multicolumn{6}{|c|}{ Household Characteristics \& Asset Ownership } \\
\hline Education & Respondent's level of education, years & 8.15 & 2.43 & 5.67 & 2.21 \\
\hline Household Size & Number of persons in household & 6.89 & 1.74 & 5.40 & 1.58 \\
\hline $\begin{array}{l}\text { Female Head of } \\
\text { House }\end{array}$ & $\begin{array}{l}\text { Household has a female aged } 16-65 \text { and no } \\
\text { male aged } 16-65\end{array}$ & 0.08 & 0.27 & 0.10 & 0.30 \\
\hline Mother's age, years & Age of child's mother, in years & 34.50 & 8.71 & 31.92 & 7.70 \\
\hline Land Size & $\begin{array}{l}\text { Amount of land owned by household } \\
\text { (hectares) }\end{array}$ & 1.60 & 1.30 & 0.64 & 0.55 \\
\hline $\begin{array}{l}\text { Access to pipe/tap } \\
\text { water }\end{array}$ & $\begin{array}{l}\text { Dummy indicating whether household has } \\
\text { access to water from a pipe or tap }\end{array}$ & 0.69 & 0.46 & 0.61 & 0.49 \\
\hline $\begin{array}{l}\text { Building material: } \\
\text { wood }\end{array}$ & Dummy indicating house is built of wood & 0.08 & 0.27 & 0.34 & 0.48 \\
\hline $\begin{array}{l}\text { Building material: } \\
\text { mud bricks }\end{array}$ & $\begin{array}{l}\text { Dummy indication house is built of mud } \\
\text { bricks }\end{array}$ & 0.75 & 0.44 & 0.66 & 0.48 \\
\hline Phones & $\begin{array}{l}\text { Number of cell phones owned by } \\
\text { household }\end{array}$ & 1.20 & 0.98 & 0.60 & 0.69 \\
\hline Observations & & & 99 & & 129 \\
\hline
\end{tabular}


Table 2: Respondent Dietary Diversity

Dependent Variables: Number of Food Groups Consumed by Respondent in the Last Two Days --OLS Regression with Robust Standard Errors-

\begin{tabular}{|c|c|c|}
\hline & All Food Groups (Max 16) & Non-Dairy Food Groups (Max 14) \\
\hline \multirow[t]{2}{*}{ Cow Beneficiary } & $1.17^{* * * *}$ & 0.40 \\
\hline & $(0.35)$ & $(0.31)$ \\
\hline \multirow[t]{2}{*}{ Goat Beneficiary } & 0.38 & 0.32 \\
\hline & $(0.34)$ & $(0.32)$ \\
\hline \multirow[t]{2}{*}{ Qualified } & -0.17 & -0.12 \\
\hline & $(0.35)$ & $(0.31)$ \\
\hline \multirow[t]{2}{*}{ Non-Heifer Cow } & 0.25 & 0.13 \\
\hline & $(0.17)$ & $(0.14)$ \\
\hline \multirow{2}{*}{ Non-Heifer Goat } & -0.08 & -0.04 \\
\hline & $(0.07)$ & $(0.06)$ \\
\hline \multirow[t]{2}{*}{ North } & $1.16^{* * * *}$ & $1.19^{* * * *}$ \\
\hline & $(0.41)$ & $(0.37)$ \\
\hline \multirow[t]{2}{*}{ Household Size } & $-0.25 * * *$ & $-0.24 * * *$ \\
\hline & $(0.07)$ & $(0.06)$ \\
\hline \multirow[t]{2}{*}{ Age (Respondent) } & $-0.02^{* * *}$ & -0.01 \\
\hline & $(0.01)$ & $(0.01)$ \\
\hline \multirow[t]{2}{*}{ Female head of house } & -0.48 & -0.32 \\
\hline & $(0.29)$ & $(0.27)$ \\
\hline \multirow[t]{2}{*}{ Female $<21$} & -0.10 & -0.09 \\
\hline & $(0.09)$ & $(0.08)$ \\
\hline \multirow[t]{2}{*}{ Male $<21$} & $0.18^{*}$ & $0.19^{* *}$ \\
\hline & $(0.09)$ & $(0.08)$ \\
\hline \multirow[t]{2}{*}{ Log Land Size } & $0.91^{* * * *}$ & $0.83 * * *$ \\
\hline & $(0.36)$ & $(0.31)$ \\
\hline \multirow[t]{2}{*}{ Phones } & $0.64^{* * * *}$ & $0.49^{* * *}$ \\
\hline & $(0.14)$ & $(0.13)$ \\
\hline \multirow[t]{2}{*}{ Education } & -0.04 & -0.02 \\
\hline & $(0.04)$ & $(0.03)$ \\
\hline \multirow[t]{2}{*}{ Labor } & $0.04^{* * * *}$ & $0.03^{* * * *}$ \\
\hline & $(0.01)$ & $(0.01)$ \\
\hline \multirow[t]{2}{*}{ Machetes } & $0.66^{* * * *}$ & $0.64 * * * *$ \\
\hline & $(0.16)$ & $(0.14)$ \\
\hline \multirow[t]{2}{*}{ Beef } & $0.63^{*}$ & 0.33 \\
\hline & $(0.34)$ & $(0.29)$ \\
\hline \multirow[t]{2}{*}{ Bull } & -0.58 & $-0.60^{*}$ \\
\hline & $(0.34)$ & $(0.37)$ \\
\hline \multirow[t]{2}{*}{ Pigs } & -0.11 & -0.12 \\
\hline & $(0.13)$ & $(0.11)$ \\
\hline \multirow[t]{2}{*}{ Sheep } & 0.12 & 0.07 \\
\hline & (0.13) & $(0.12)$ \\
\hline \multirow[t]{2}{*}{ Chickens } & 0.02 & 0.02 \\
\hline & $(0.01)$ & $(0.01)$ \\
\hline \multirow[t]{2}{*}{ Rabbits } & $0.21^{*}$ & $0.17^{*}$ \\
\hline & $(0.11)$ & $(0.10)$ \\
\hline \multirow[t]{2}{*}{ Constant } & $5.54^{* * * *}$ & 5.01 **** \\
\hline & $(0.73)$ & $(0.64)$ \\
\hline Observations & 369 & 369 \\
\hline R-squared & 0.44 & 0.39 \\
\hline
\end{tabular}

Robust standard errors in parentheses, ${ }^{*} \mathrm{p}<.1,{ }^{*} * \mathrm{p}<0.05,{ }^{*} * * \mathrm{p}<0.01$ 
Table 3: Respondent Dairy and Meat Consumption

Dependent Variables: Respondent Consumption in the Last Two Days (Frequency) --Poisson Regression-

\begin{tabular}{|c|c|c|}
\hline & $\begin{array}{c}\text { Dairy Consumption } \\
\text { (Frequency) }\end{array}$ & Meat Consumption (Frequency) \\
\hline \multirow[t]{2}{*}{ Cow Beneficiary } & $1.20^{* * * *}$ & -0.26 \\
\hline & $(0.20)$ & $(0.29)$ \\
\hline \multirow[t]{2}{*}{ Goat Beneficiary } & 0.27 & 0.06 \\
\hline & $(0.35)$ & $(0.47)$ \\
\hline \multirow[t]{2}{*}{ Qualified } & -0.18 & -0.21 \\
\hline & $(0.30)$ & $(0.32)$ \\
\hline \multirow[t]{2}{*}{ Non-Heifer Cow } & $0.18^{* *}$ & 0.12 \\
\hline & $(0.08)$ & (0.08) \\
\hline \multirow[t]{2}{*}{ Non-Heifer Goat } & $-0.07^{*}$ & -0.02 \\
\hline & $(0.05)$ & $(0.09)$ \\
\hline \multirow[t]{2}{*}{ North } & 0.35 & 0.52 \\
\hline & $(0.30)$ & $(0.38)$ \\
\hline \multirow[t]{2}{*}{ Household Size } & -0.02 & $-0.27 * * *$ \\
\hline & $(0.04)$ & $(0.06)$ \\
\hline \multirow[t]{2}{*}{ Age (Respondent) } & $-0.02 * *$ & $-0.01^{*}$ \\
\hline & $(0.01)$ & $(0.01)$ \\
\hline \multirow[t]{2}{*}{ Female head of house } & $-0.29^{*}$ & 0.02 \\
\hline & $(0.17)$ & $(0.34)$ \\
\hline \multirow[t]{2}{*}{ Female $<21$} & 0.05 & 0.06 \\
\hline & $(0.06)$ & 0.08 \\
\hline \multirow[t]{2}{*}{ Male $<21$} & 0.00 & 0.07 \\
\hline & 0.06 & $(0.09)$ \\
\hline \multirow[t]{2}{*}{ Log Land Size } & 0.03 & $0.48^{*}$ \\
\hline & $(0.26)$ & $(0.28)$ \\
\hline \multirow[t]{2}{*}{ Phones } & $0.26^{* * *}$ & $0.23^{* *}$ \\
\hline & $(0.07)$ & $(0.12)$ \\
\hline \multirow[t]{2}{*}{ Education } & $-0.06^{* * *}$ & $-0.10^{* * * *}$ \\
\hline & $(0.02)$ & $(0.03)$ \\
\hline \multirow[t]{2}{*}{ Labor } & 0.01 & 0.00 \\
\hline & $(0.00)$ & $(0.01)$ \\
\hline \multirow[t]{2}{*}{ Machetes } & 0.00 & $0.44^{* * * *}$ \\
\hline & (0.09) & $(0.12)$ \\
\hline \multirow[t]{2}{*}{ Beef } & $0.26^{* * *}$ & -0.05 \\
\hline & $(0.10)$ & $(0.27)$ \\
\hline \multirow[t]{2}{*}{ Bull } & 0.08 & -0.15 \\
\hline & $(0.17)$ & $(0.27)$ \\
\hline \multirow[t]{2}{*}{ Pigs } & -0.05 & -0.01 \\
\hline & (0.09) & $(0.07)$ \\
\hline \multirow[t]{2}{*}{ Sheep } & 0.10 & 0.03 \\
\hline & $(0.07)$ & $(0.15)$ \\
\hline \multirow[t]{2}{*}{ Chickens } & $-0.01 *$ & -0.07 \\
\hline & $(0.01)$ & $(0.07)$ \\
\hline \multirow[t]{2}{*}{ Rabbits } & $0.10^{* *}$ & 0.03 \\
\hline & $(0.04)$ & $(0.05)$ \\
\hline \multirow[t]{2}{*}{ Constant } & 0.34 & -0.03 \\
\hline & $(0.47)$ & $(0.64)$ \\
\hline Observations & 369 & 369 \\
\hline
\end{tabular}


Table 4: Household Dairy and Meat Consumption

Dependent Variables: Monthly Household Consumption Per-Person --Tobit Regression with Robust Standard Errors-

\begin{tabular}{|c|c|c|}
\hline & $\begin{array}{c}\text { Dairy Consumption } \\
\text { (Liters) }\end{array}$ & Meat Consumption (Kilograms) \\
\hline \multirow[t]{2}{*}{ Cow Beneficiary } & $9.34^{* * * *}$ & -0.21 \\
\hline & $(1.34)$ & $(0.15)$ \\
\hline \multirow[t]{2}{*}{ Goat Beneficiary } & -0.33 & $0.20^{*}$ \\
\hline & $(0.92)$ & $(0.11)$ \\
\hline \multirow[t]{2}{*}{ Qualified } & 0.99 & -0.06 \\
\hline & $(0.83)$ & $(0.10)$ \\
\hline \multirow[t]{2}{*}{ Non-Heifer Cow } & $3.32 * * *$ & 0.02 \\
\hline & $(0.58)$ & $(0.08)$ \\
\hline \multirow[t]{2}{*}{ Non-Heifer Goat } & -0.36 & -0.01 \\
\hline & $(0.24)$ & $(0.03)$ \\
\hline \multirow[t]{2}{*}{ North } & 1.06 & $0.29^{* *}$ \\
\hline & $(1.07)$ & $(0.12)$ \\
\hline \multirow[t]{2}{*}{ Household Size } & $-0.99^{* * * *}$ & $-0.10^{* * * *}$ \\
\hline & $(0.21)$ & $(0.02)$ \\
\hline \multirow[t]{2}{*}{ Age (Respondent) } & -0.05 & $-0.01^{*}$ \\
\hline & $(0.03)$ & $(0.00)$ \\
\hline \multirow[t]{2}{*}{ Female head of house } & -0.81 & -0.09 \\
\hline & $(1.02)$ & $(0.10)$ \\
\hline \multirow[t]{2}{*}{ Female $<21$} & $0.45^{*}$ & 0.04 \\
\hline & $(0.27)$ & $(0.03)$ \\
\hline \multirow[t]{2}{*}{ Male $<21$} & -0.03 & -0.03 \\
\hline & $(0.31)$ & $(0.03)$ \\
\hline \multirow[t]{2}{*}{ Log Land Size } & 1.60 & $0.32^{* *}$ \\
\hline & $(1.30)$ & $(0.14)$ \\
\hline \multirow[t]{2}{*}{ Phones } & $1.32 * * *$ & $0.12^{* *}$ \\
\hline & $(0.47)$ & $(0.05)$ \\
\hline \multirow[t]{2}{*}{ Education } & 0.02 & -0.01 \\
\hline & $(0.11)$ & (0.01) \\
\hline \multirow[t]{2}{*}{ Labor } & 0.02 & 0.00 \\
\hline & (0.03) & $(0.00)$ \\
\hline \multirow[t]{2}{*}{ Machetes } & -0.10 & $0.21 * * *$ \\
\hline & $(0.57)$ & $(0.06)$ \\
\hline \multirow[t]{2}{*}{ Beef } & -0.03 & -0.02 \\
\hline & $(0.62)$ & $(0.07)$ \\
\hline \multirow[t]{2}{*}{ Bull } & 2.39 & 0.15 \\
\hline & $(1.76)$ & $(0.16)$ \\
\hline \multirow[t]{2}{*}{ Pigs } & -0.11 & $0.08^{*}$ \\
\hline & $(0.50)$ & $(0.04)$ \\
\hline \multirow[t]{2}{*}{ Sheep } & 0.19 & $0.16^{* * *}$ \\
\hline & $(0.52)$ & $(0.06)$ \\
\hline \multirow[t]{2}{*}{ Chickens } & $-0.11^{* *}$ & 0.02 \\
\hline & $(0.05)$ & $(0.02)$ \\
\hline \multirow[t]{2}{*}{ Rabbits } & 0.16 & -0.03 \\
\hline & $(0.50)$ & (0.04) \\
\hline \multirow[t]{2}{*}{ Constant } & 3.29 & 0.26 \\
\hline & $(2.08)$ & $(0.24)$ \\
\hline Observations & 322 & 284 \\
\hline
\end{tabular}


Table 5: Household Dairy and Meat Consumption

Dependent Variables: Monthly Household Consumption Per-Person

--Propensity Score Matching and Nearest Neighbor Matching-

\begin{tabular}{lcc}
\hline & $\begin{array}{c}\text { Dairy Cow } \\
\text { Milk Consumption } \\
\text { (Liters) }\end{array}$ & $\begin{array}{c}\text { Meat Goat } \\
\text { Meat Consumption } \\
\text { (Kilograms) }\end{array}$ \\
\hline $\begin{array}{l}\text { Propensity Score Matching: ATT Coefficient } \\
\text { Bootstrapped } \boldsymbol{S E}\end{array}$ & 10.91 & 0.11 \\
Rosenbaum Bounds Gamma $(\boldsymbol{\Gamma})$ & $(1.41)$ & $(0.11)$ \\
& 9.5 & 1 \\
Nearest Neighbor Matching: ATT Coefficient & & 0.17 \\
Standard error & 10.23 & $(0.09)$ \\
\hline
\end{tabular}

Table 6a: Nutritional Status of Children

\begin{tabular}{ccccccc}
\hline & \multicolumn{2}{c}{ HAZ } & \multicolumn{2}{c}{ WHZ } & \multicolumn{2}{c}{ WAZ } \\
& North & East & North & East & North & East \\
\hline $\begin{array}{c}\text { Percentage of } \\
\text { Children }\end{array}$ & & & & & & \\
Normal & $40.8 \%$ & $50.0 \%$ & $88.8 \%$ & $88.1 \%$ & $67.3 \%$ & $62.2 \%$ \\
Mild & $36.7 \%$ & $25.4 \%$ & $11.2 \%$ & $8.7 \%$ & $23.5 \%$ & $22.8 \%$ \\
Moderate & $11.2 \%$ & $15.1 \%$ & $0.0 \%$ & $2.4 \%$ & $6.1 \%$ & $13.4 \%$ \\
Severe & $11.2 \%$ & $9.5 \%$ & $0.0 \%$ & $0.8 \%$ & $3.1 \%$ & $1.6 \%$ \\
\hline
\end{tabular}

${ }^{a}$ Categories of wasting, stunting, and underweight are based on $\mathrm{z}$-scores, where $\mathrm{z} \geq-1.0$ is normal, $-1.0>\mathrm{z}$ $\geq-2.0$ is mild malnutrition, $-2.0>\mathrm{z} \geq-3.0$ is moderate malnutrition, and $\mathrm{z}<-3.0$ is severe malnutrition.

Table 6b: Comparison to Rwandan Country Profile

\begin{tabular}{cccc}
\hline \multicolumn{4}{c}{ Moderate and Severe Malnutrition } \\
\hline & Stunting & Wasting & Underweight \\
& $(\mathbf{H A Z}<-\mathbf{- 2})$ & $(\mathbf{W H Z}<-\mathbf{2})$ & $(\mathbf{W A Z}<-\mathbf{- 2})$ \\
Sample & $23.7 \%$ & $1.8 \%$ & $12.4 \%$ \\
National $^{\mathrm{b}}$ & $44.3 \%$ & $3.0 \%$ & $11.7 \%$ \\
\hline
\end{tabular}

b Taken from WHO’s Nutrition Landscape Information System, Country Profile: Rwanda (2010-11). 
Table 7: Estimated Effects on Child Nutritional Status

Dependent Variables: Height for Age z-score, Weight for Height z-score, Weight for Age z-score --Seemingly Unrelated Regressions--

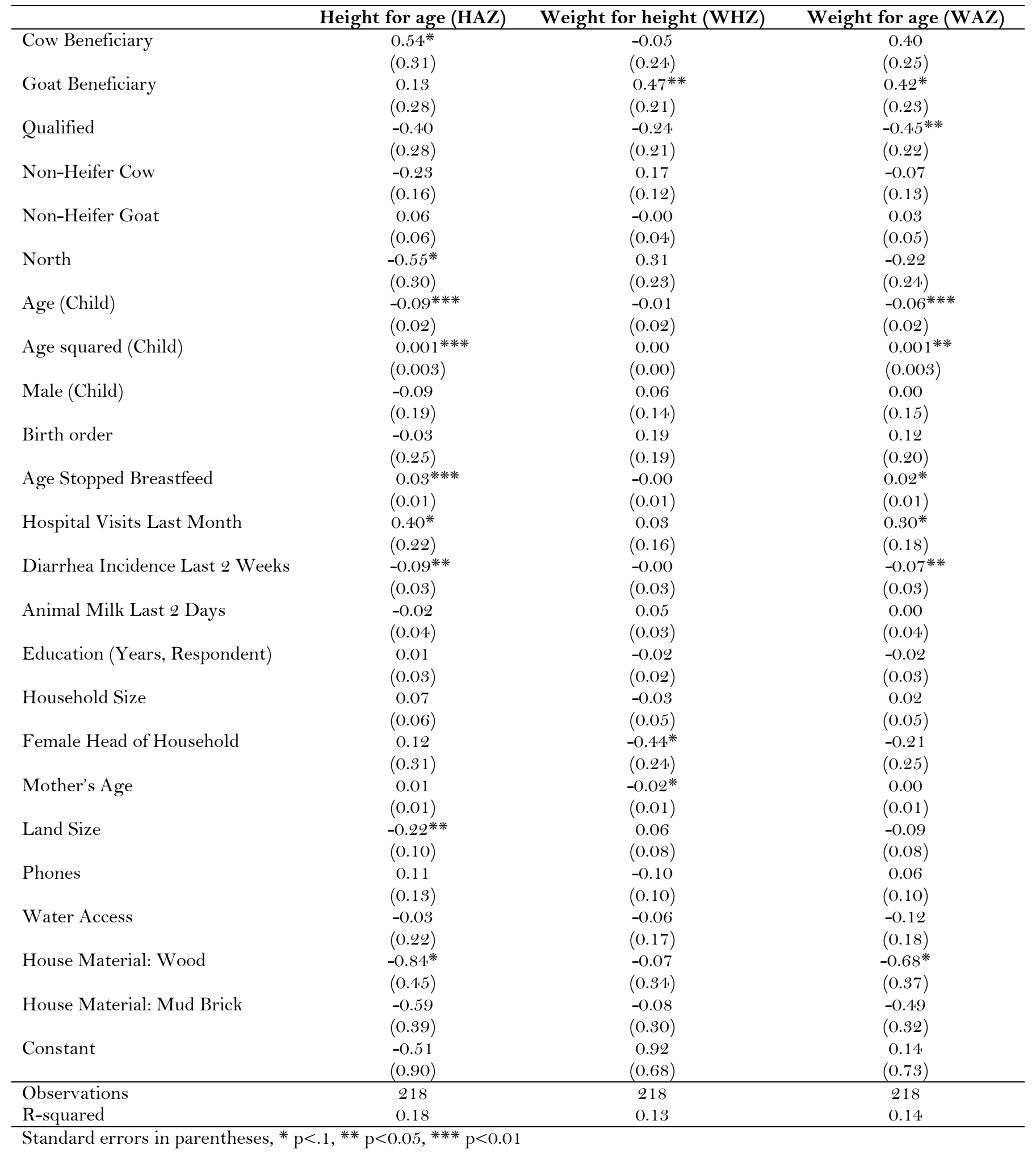


Table 8: Estimated Effects on HAZ, WHZ \& WAZ

Dependent Variables: Height for Age z-score, Weight for Height z-score, Weight for Age z-score --Propensity Score Matching and Nearest Neighbor Matching--

\begin{tabular}{|c|c|c|c|c|}
\hline Treatment & & HAZ & WHZ & WAZ \\
\hline \multirow{5}{*}{$\begin{array}{c}\text { Dairy Cow } \\
\text { Donation }\end{array}$} & Propensity Score Matching: ATT & 0.75 & 0.03 & 0.19 \\
\hline & Bootstrapped Standard Error & $(0.54)$ & $(0.29)$ & $(0.52)$ \\
\hline & Balancing Property Satisfied & Yes & Yes & Yes \\
\hline & Nearest Neighbor Matching: ATT & 0.25 & -0.19 & -0.01 \\
\hline & Standard Error & $(0.31)$ & $(0.27)$ & $(0.30)$ \\
\hline \multirow{5}{*}{$\begin{array}{c}\text { Meat Goat } \\
\text { Donation }\end{array}$} & Propensity Score Matching: ATT & 0.47 & 0.41 & 0.29 \\
\hline & Bootstrapped Standard Error & $(0.52)$ & $(0.33)$ & $(0.39)$ \\
\hline & Balancing Property Satisfied & No & No & No \\
\hline & Nearest Neighbor Matching: ATT & 0.46 & $0.47 *$ & $0.76^{* *}$ \\
\hline & Standard Error & $(0.41)$ & $(0.27)$ & $(0.32)$ \\
\hline
\end{tabular}




\section{Appendix A: Dietary Diversity Survey}

In the last 2 days, how many times did you (adult taking survey) eat:

\section{A) STAPLE FOODS}

1) Starchy fruits such as cooking banana, matoke?

2) Cassava, yams, sweet potatoes, Irish potatoes or other roots and tubers?

3) Rice, posho, porridge, bread, chapatti, pasta/macaroni, pizza, or other foods made from maize, millet, sorghum or other grains?

B) PROTEIN

4) Beans, peas, cow peas, nuts, seeds, oil seeds, soya beans or other legumes or seeds?

5) Meat (beef, pork, goat, lamb, chicken, duck) or other meat?

6) Eggs (Chicken eggs, duck eggs etc)?

7) Fresh fish, dry fish or shell fish?

\section{C) VEGETABLES AND FRUITS}

8) Dark green leafy vegetables like spinach, isombe?

9) Orange-colored vegetables such as pumpkins, carrots, orange fleshed sweet potatoes?

10) Any bio-fortified food (Orange-fleshed sweet potatoes)?

11) Orange colored fruits like ripe mangoes, pawpaw?

12) Other fruits or vegetables (passion fruit, jack fruit, pineapples, oranges etc)?

D) OTHER FOODS

13) Any milk?

14) Cheese, yogurt, or other milk products?

15) Cooking oil, margarine, butter or other oils/fats?

16) Any sugary foods such as chocolates, sweets, candies pastries, cakes or biscuits? 


\section{Appendix B1: Selection into Treatment - Dietary Diversity}

Dependent Variables: Cow Beneficiary, Goat Beneficiary --Probit Estimation--

\begin{tabular}{lcc}
\hline & Dairy Cow Beneficiary & Meat Goat Beneficiary \\
\hline Age & -0.01 & -0.1 \\
Education & $(0.01)$ & $(0.01)$ \\
& 0.05 & $0.10^{* * *}$ \\
Household Size & $(0.04)$ & $(0.04)$ \\
& 0.04 & $-0.13^{*}$ \\
Log Land Size & $(0.06)$ & $(0.08)$ \\
& 0.40 & 0.45 \\
Female Head of House & $(0.28)$ & $(0.39)$ \\
& 0.03 & -0.22 \\
Female $<21$ & $(0.30)$ & $(0.36)$ \\
& $-0.20^{* *}$ & 0.17 \\
Male $<21$ & $(0.09)$ & $(0.11)$ \\
& -0.08 & 0.01 \\
Constant & $(0.11)$ & $(0.11)$ \\
& 0.06 & 0.85 \\
$\mathrm{~N}$ & $(0.77)$ & $(0.63)$ \\
Pseudo R & 133 & 121 \\
\hline
\end{tabular}

Standard errors in parentheses, $* \mathrm{p}<.1$, ** $\mathrm{p}<0.05$, *** $\mathrm{p}<0.01$

\section{Probit Post-Estimation Classification}

\begin{tabular}{|c|c|c|c|c|}
\hline & \multicolumn{2}{|c|}{ Dairy Cow Beneficiary } & \multicolumn{2}{|c|}{ Meat Goat Beneficiary } \\
\hline & 0.50 Cut-off & 0.48 Cut-offa $^{\mathrm{a}}$ & 0.50 Cut-off & O.60 Cut-offa \\
\hline Sensitivity & $71.62 \%$ & $75.68 \%$ & $91.36 \%$ & $80.25 \%$ \\
\hline Specificity & $42.37 \%$ & $37.29 \%$ & $30.00 \%$ & $47.50 \%$ \\
\hline Correctly Classified & $58.65 \%$ & $58.65 \%$ & $71.07 \%$ & $69.42 \%$ \\
\hline Balancing property $s$ & \multicolumn{2}{|c|}{ Yes } & \multicolumn{2}{|c|}{ Yes } \\
\hline
\end{tabular}

aProportion of treated households as the cut-off rate 
Appendix B2: Selection into Treatment - Child Nutritional Status

(Sample: Households with Children 0-5 Years Old)

Dependent Variables: Cow Beneficiary, Goat Beneficiary --Probit Estimation--

\begin{tabular}{|c|c|c|}
\hline & Dairy Cow Beneficiary & Meat Goat Beneficiary \\
\hline \multirow[t]{2}{*}{ Age (Child) } & 0.00 & 0.01 \\
\hline & $(0.02)$ & $(0.01)$ \\
\hline \multirow[t]{2}{*}{ Male (Child) } & $-0.63^{*}$ & -0.42 \\
\hline & $(0.34)$ & $(0.29)$ \\
\hline \multirow[t]{2}{*}{ Birth order } & 0.34 & -0.21 \\
\hline & $(0.40)$ & $(0.35)$ \\
\hline \multirow[t]{2}{*}{ Age Stopped Breastfeed } & -0.02 & $-0.03^{*}$ \\
\hline & $(0.02)$ & $(0.02)$ \\
\hline \multirow[t]{2}{*}{ Education (Respondent) } & -0.01 & $0.11^{* *}$ \\
\hline & $(0.06)$ & $(0.05)$ \\
\hline \multirow[t]{2}{*}{ Mother's Age } & -0.02 & 0.03 \\
\hline & $(0.02)$ & $(0.02)$ \\
\hline \multirow[t]{2}{*}{ Household Size } & -0.02 & -0.16 \\
\hline & $(0.10)$ & $(0.11)$ \\
\hline \multirow[t]{2}{*}{ Female Household Head } & -0.73 & 0.28 \\
\hline & $(0.58)$ & $(0.53)$ \\
\hline \multirow[t]{2}{*}{ House Material: Mud Brick } & $0.81^{* *}$ & $-0.54^{*}$ \\
\hline & $(0.35)$ & $(0.33)$ \\
\hline \multirow[t]{2}{*}{ Constant } & 0.66 & 0.91 \\
\hline & $(1.06)$ & $(0.94)$ \\
\hline $\mathrm{N}$ & 85 & 102 \\
\hline Pseduo $\mathrm{R}^{2}$ & 0.13 & 0.15 \\
\hline
\end{tabular}

Probit Post-Estimation Classification

\begin{tabular}{lccc}
\hline & Dairy Cow Donations & \multicolumn{2}{c}{ Meat Goat Donations } \\
\hline & 0.50 Cut-off & 0.50 Cut-off & 0.60 Cut-off \\
\cline { 2 - 4 } Sensitivity & $65.11 \%$ & $85.48 \%$ & $67.74 \%$ \\
Specificity & $61.90 \%$ & $45.00 \%$ & $65.00 \%$ \\
Correctly Classified & $63.53 \%$ & $69.61 \%$ & $66.67 \%$ \\
\hline
\end{tabular}

aProportion of treated households as the cut-off rate (0.50 in the case of dairy cow donations). 